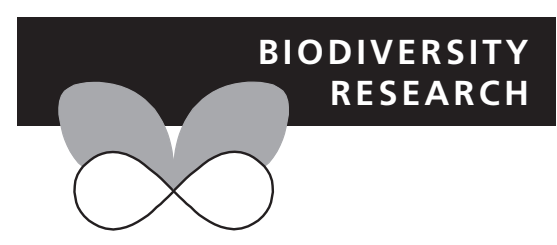

\title{
Predicting biological invasions in marine habitats through eco-physiological mechanistic models: a case study with the bivalve Brachidontes pharaonis
}

\author{
G. Sarà ${ }^{1 \star}$, V. Palmeri ${ }^{1}$, A. Rinaldi ${ }^{1,2}$, V. Montalto ${ }^{1}$ and B. Helmuth ${ }^{3, \dagger}$
}

${ }^{1}$ Dipartimento di Scienze della Terra e del Mare, Università di Palermo, Viale delle Scienze Ed. 16, 90128 Palermo, Italy, ${ }^{2}$ Dipartimento di Scienze Biologiche e Ambientali, Università di Messina, Salita Sperone 31, 98166 Messina, Italy, ${ }^{3}$ Marine Science Center, Northeastern University, 430 Nahant Rd, Nahant, MA, USA

${ }^{*}$ Correspondence: Gianluca Sarà, Dipartimento di Scienze della Terra e del Mare, Università di Palermo, Viale delle Scienze Ed. 16, 90128 Palermo, Italy. E-mail: gianluca.sara@unipa.it

${ }^{\dagger}$ Present address: Marine Science Center, Northeastern University, Nahant, MA, USA

\begin{abstract}
Aim We used a coupled biophysical ecology (BE)-physiological mechanistic modelling approach based on the Dynamic Energy Budget theory (DEB, Dynamic energy budget theory for metabolic organisation, 2010, Cambridge University Press, Cambridge; DEB) to generate spatially explicit predictions of physiological performance (maximal size and reproductive output) for the invasive mussel, Brachidontes pharaonis.
\end{abstract}

Location We examined 26 sites throughout the central Mediterranean Sea.

Methods We ran models under subtidal and intertidal conditions; hourly weather and water temperature data were obtained from the Italian Buoy Network, and monthly CHL- $a$ data were obtained from satellite imagery.

Results Mechanistic analysis of the B. pharaonis fundamental niche shows that subtidal sites in the Central Mediterranean are generally suitable for this invasive bivalve but that intertidal habitats appear to serve as genetic sinks.

Main conclusions A BE-DEB approach enabled an assessment of how the physical environment affects the potential distribution of B. pharaonis. Combined with models of larval dispersal, this approach can provide estimates of the likelihood that an invasive species will become established.

\section{Keywords}

Bivalves, Dynamic Energy Budget model, fundamental niche, invasive species, life-history traits, Mediterranean Sea.

\section{INTRODUCTION}

The ability to predict the physiological performance and fitness (Stearns, 1992) of invasive species is crucial for understanding the dynamics of biological invasions in marine ecosystems. The likely spread and establishment of a non-native species in a new habitat is the product of the likelihood that adults, juveniles or larvae of the invader are transported to the new location, the physiological suitability of that habitat for the potential invader and the ways in which these organisms interact with native species (Sarà et al., in press-b). Recent studies have emphasized that while extreme environmental conditions can serve as important barriers to range edges, sublethal effects such as reproductive failure may also play a key role (e.g. Petes et al., 2007). Most approaches to predicting species invasions in use today are parameterized using correlations between current range edges and environmental parameters at those locations. Especially in the case of potential invasive species, existing range boundaries (i.e. realized niche space) may not always serve as an effective indicator of that species physiological limits (fundamental niche space). For example, several studies have pointed to the importance of local environmental conditions, which can over-ride larger-scale geographic gradients in parameters such as temperature, and which can lead to high levels of heterogeneity over latitudinal scales (Helmuth et al., 2006; Mislan et al., 2011).

The ability to quantitatively predict levels of growth and reproduction by invasive species is especially important in the context of climate change (Lika et al., 2011), which has the potential to open previously uncolonized areas to invasion as environmental conditions change, or as new modes of transport such as ship ballast water arise (Simberloff, 2009). Many factors affect a species' metapopulation 
dynamics, including patterns of larval dispersal, the amount of time that larvae in the water column remain competent to settle (O'Connor et al., 2007) and the local density and spatial distribution of reproductive adults. Thus the body size, number of reproductive bouts and time to reproductive maturity (puberty; Roff, 1992) are crucial life-history parameters affecting the larval dispersal of most marine organisms (Hughes et al., 2005), and the local persistence of populations over time (Simberloff, 2009; Kearney et al., 2010). While considerable progress has been made predicting patterns of larval competency and dispersal (e.g. Menge \& Olson, 1990; McQuaid \& Phillips, 2006; Dong et al., 2012), understanding and predicting the spatial distribution of physiologically suitable habitat and larval production has remained problematic.

Recent mechanistic eco-physiological models such as Dynamic Energy Budget approaches (DEB; Kooijman, 2010) can potentially provide a powerful tool for predicting patterns of reproduction and other sublethal responses to environmental change, especially when coupled with spatially and temporally explicit predictions of how the physical environment affects organismal parameters such as body temperature (BT; Kearney et al., 2010). Such methods are important because recent studies have emphasized that the first impacts of climate change may lie in sublethal responses such as changes in growth and reproduction (Monaco \& Helmuth, 2011; Wethey et al., 2011) and that evidence of these impacts has been found well inside species ranges (Beukema et al., 2009). The mechanistic nature of the DEB theory provides an exceptionally powerful tool to predict organismal function according to physical principles (Kearney, 2012). Several recent studies have shown that coupled heat budget (biophysical ecology, BE) and DEB modelling approaches can be used effectively to predict population-level responses to environmental change. However, such methods have yet to be applied to invasive marine species.

Here, using a mechanistic approach based on coupled BE-DEB theory, we modelled the fitness of an invasive Lessepsian bivalve, the Pharaonic mussel Brachidontes pharaonis at multiple sites throughout the Italian Mediterranean. Brachidontes pharaonis entered the Mediterranean from the Red Sea after the Suez canal opened in 1869 (Safriel \& Sasson-Frostig, 1988; Sarà et al., 2000, 2008; Rilov et al., 2004; Sarà, 2006). This species is considered to be intertidal, as it has been reported in the Mediterranean in lower intertidal (Rilov et al., 2004) and shallow subtidal environments such as lagoons (Sarà et al., 2000; Cilia \& Deidun, 2012). Brachidontes pharaonis is listed among the 100 worst invasive species in the Mediterranean (Galil, 2007). This species has a cosmopolitan distribution (Sarà et al., 2003; Sarà \& De Pirro, 2011) and colonizes valuable ecosystems like Dendropoma reefs (Chemello \& Silenzi, 2011) outcompeting native gastropods and bivalves (Rilov et al., 2004).

The specific aims of this study were: (1) to quantitatively predict differences in reproductive output in B. pharaonis, in subtidal and intertidal $(+35 \mathrm{~cm}$ above Mean Lower Low
Water) populations; (2) to identify the localities where B. pharaonis would reach maximal fitness and null fitness (i.e. reproductive failure) throughout the central Mediterranean and (3) predict patterns of suitable habitat and thus possible colonization routes in the near future that will likely result from environmental change.

\section{METHODS}

\section{Study area and environmental inputs}

We ran DEB models with BT and food as forcing drivers of life history of B. pharaonis (Sarà et al., in press-b) throughout the central Mediterranean Sea (Fig. 1). In particular, we performed DEB simulations using food and water temperature datasets from 26 sites around the Italian Peninsula, from the Gulf of Tigullio northernmost (LAT c. $44^{\circ}$ ) up to the Gulf of Gabes (LAT c. 33 $3^{\circ}$; Tunisia) southernmost and from the western Sardinia (LONG c. $8^{\circ}$ ) to the eastern part of the Adriatic Sea (LONG c. $19^{\circ}$ ).

Dynamic Energy Budget models (Fig. 2) were run simulating both subtidal (i.e. always immersed) and intertidal (e.g. immersed at low tide and submerged at high tide) conditions. BT for submerged animals (subtidal or intertidal at high tide) was assumed to be the same as water temperature (Lima et al., 2011). We used the hourly seawater temperatures (1 January 2006-31 December 2009) measured about $1 \mathrm{~m}$ below the surface by the Italian Oceanographic Buoy Network maintained at ISPRA (http://www.mareografico.it/).

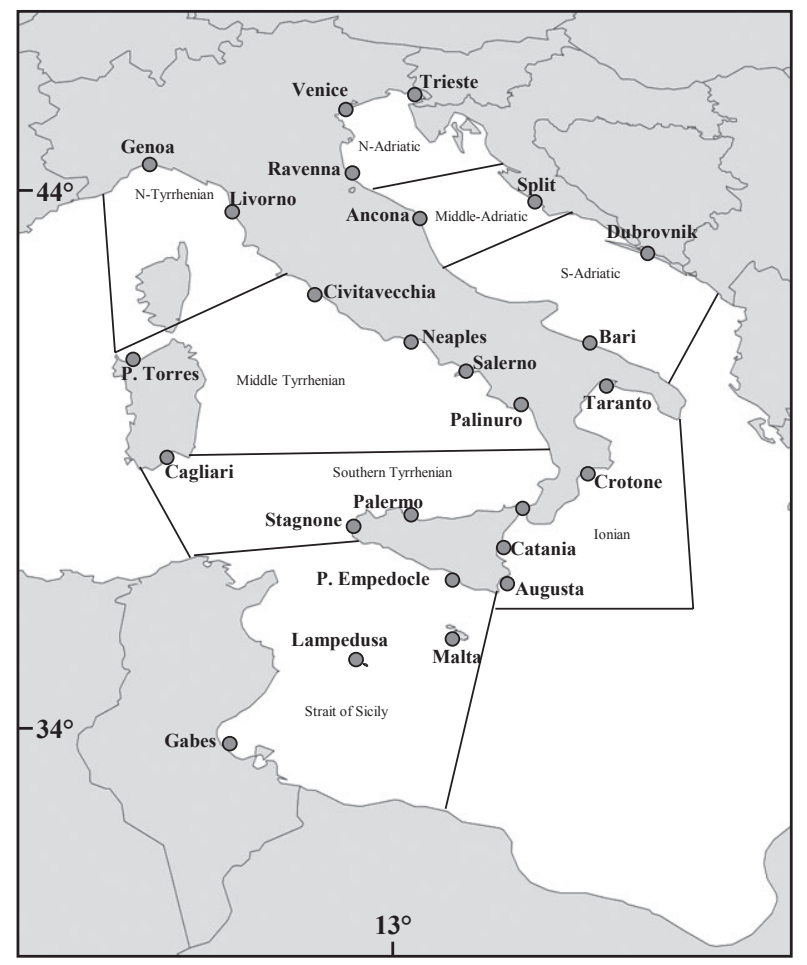

Figure 1 Map showing all sites considered in this study. 
During aerial exposure at low tide, BT is driven by multiple environmental factors, and is moreover affected by the body size and morphology of the organism (Helmuth, 1998). We used a BE heat budget model (see Kearney et al., 2010; Helmuth et al., 2011 for details) that was integrated with the DEB model so that the output of the BE model served as the source for the BT in the DEB routine for intertidal conditions (Kearney et al., 2010; Sarà et al., 2011, in press-b). Hourly weather data for the BE model (hourly air temperature, tide amplitude, wind speed) were obtained from the ISPRA Buoy Network; daily irradiance data were downloaded from the European Commission Joint Research Centre (2012; http://re.jrc.ec.europa.eu/pvgis/apps4/pvest.php; for details on biophysical models and recent applications in a DEB context, see Helmuth et al., 2011; Kearney et al., 2010, 2012; Sarà et al., 2011; Kearney, 2012).

Water temperatures were obtained for the Gulf of Gabes (Tunisia), Dubrovnik and Split (Croatia) using datasets of the closest Italian buoys (Lampedusa, Bari and Ancona, respectively; Fig. 1) as there are no local, continuous hourly temporal series for Tunisia and Croatia yet available.

Chlorophyll- $a$ (CHL- $a$ ) from satellite imagery was used to estimate the amount of food available to suspension feeders (Kearney et al., 2010; Sarà et al., 2011, 2012, in press-b). We used monthly data for CHL- $a\left(\mu \mathrm{g} \mathrm{l}^{-1}\right)$ from January 1998 to December 2007 (i.e. 120 point-months) from the EMIS website (http://emis.jrc.ec.europa.eu). We downloaded data from a horizontal grid spacing of $30 \mathrm{~km}$ positioned on the sea around every ISPRA oceanographic station. Areas were c. $10 \mathrm{~km}$ from the coast to avoid the interference of reflectance due to the presence of the landmass. We obtained 12 mean values (January-December) for every location using 10 years data (1998-2007). The lack of high resolution CHL$a$ data is therefore a potential limitation to our approach, and the use of averages therefore ignores any potential effects of interannual variability in CHL- $a$. We therefore focus on the effects of changes in BT.

Our model assumed that at low tide, mussels could not feed except during wave splash, which was estimated by integrating wind and wave height into a biophysical model (see Sarà et al., 2011). Thus, under subtidal conditions, we assumed that the feeding time occurred constantly, while under intertidal the feeding time was a function of low-tideexposure time modified by wave splash. We assumed that temperature-dependent physiological rates during aerial exposure were the same as those during submersion, except for food intake (Kearney et al., 2010; Sarà et al., 2011). Simulations were run for 4 years (1 January 2006-31 December 2009) using Brachidontes DEB parameters (Table 1) at each location both under subtidal and intertidal conditions, using food and temperature parameters as described above. Outputs were (Sarà et al., in press-b): (1) the maximum theoretical total shell length (TL, cm) reached by mussels; (2) maturation time, in days; (3) the number of reproductive events (RE, $n$ ) throughout the simulated 4-year period; (4) the total reproductive outputs (TRO, $n$ ) i.e. the number of eggs produced per biomass unit (dry weight) throughout 4 years; and (5) the number of eggs produced per reproductive event (i.e. TRO/RE).

\section{DEB model validation}

Throughout the 2009 and 2010, we collected more than 1000 animals from the saltpan of the close Stagnone di Marsala where this species has established highly dense populations (Sarà et al., 2000). We estimated the age of each animal through the analysis of shell rings using the technique described in Peharda et al. (2012; Sarà et al., in press-b), longitudinally cutting shells with a Dremel rotary tool (Series 4000; Robert Bosch Tool Corporation Inc., Stuttgart, Germany).

We sampled bi-monthly (six samples per year) water and sediments and estimated the amount phyto-pigments (chlorophyll-a) according to methods reported in Pusceddu et al. (1997) and Sarà (2009). Temperature and food density (as expressed by the concentration of chlorophyll- $a$ ) were used to run DEB models of $B$. pharaonis in the Stagnone di Marsala. With these local data, we obtained the Von Bertalanffy infinite size through DEB models and compared it

Table 1 Parameters used for the Dynamic Energy Budget models (Palmeri, 2011; Sarà et al., in press-b; parameters are posted at: http://www.bio.vu.nl/thb/deb/deblab/add_my_pet/ index.php)

\begin{tabular}{|c|c|c|}
\hline Parameter & Unit & $\begin{array}{l}\text { Brachidontes } \\
\text { pharaonis }\end{array}$ \\
\hline $\begin{array}{l}\{J X m\} \text {, Maximum surface } \\
\text { area-specific ingestion rate }\end{array}$ & $\mathrm{J} \mathrm{cm}^{-2} \mathrm{~h}^{-1}$ & 17.88 \\
\hline $\begin{array}{l}{\left[p^{\cdot} M\right], \text { Volume-specific }} \\
\text { maintenance cost }\end{array}$ & $\mathrm{J} \mathrm{cm}^{-3} \mathrm{~h}^{-1}$ & 9.29 \\
\hline $\begin{array}{l}{\left[E_{\mathrm{m}}\right], \text { Maximum storage }} \\
\text { density }\end{array}$ & $\mathrm{J} \mathrm{cm}{ }^{3}$ & 1,967 \\
\hline $\begin{array}{l}{\left[E_{\mathrm{G}}\right] \text {, Volume-specific cost }} \\
\text { of growth }\end{array}$ & $\mathrm{J} \mathrm{\textrm {cm } ^ { 3 }}$ & 1,118 \\
\hline $\begin{array}{l}\kappa, \text { Fraction of mobilized } \\
\text { reserve spent on soma }\end{array}$ & - & 0.9874 \\
\hline$\delta m$, Shape coefficient & - & 0.288 \\
\hline$V_{\mathrm{b}}$, Structural volume at birth & $\mathrm{cm}^{3}$ & 0.00000049 \\
\hline $\begin{array}{l}V_{\mathrm{p}}, \text { Structural volume } \\
\text { at puberty }\end{array}$ & $\mathrm{cm}^{3}$ & 0.01008 \\
\hline$A_{\mathrm{e}}$, Assimilation efficiency & - & 0.75 \\
\hline$X_{\mathrm{k}}$, Saturation coefficient & $\mu \mathrm{g}$ chl- $a \mathrm{l}^{-1}$ & 0.62 \\
\hline $\begin{array}{l}k_{\mathrm{R}} \text {, Fraction reproductive } \\
\text { energy fixed }\end{array}$ & - & 0.95 \\
\hline$T_{\mathrm{A}}$, Arrhenius temperature & ${ }^{\circ} \mathrm{K}$ & 8232 \\
\hline $\begin{array}{l}T_{\mathrm{L}}, \text { Lower boundary of } \\
\text { tolerance range }\end{array}$ & ${ }^{\circ} \mathrm{K}$ & 284 \\
\hline $\begin{array}{l}T_{\mathrm{H}} \text {, Upper boundary of } \\
\text { tolerance range }\end{array}$ & ${ }^{\circ} \mathrm{K}$ & 305 \\
\hline $\begin{array}{l}T_{\mathrm{AL}}, \text { Rate of decrease at } \\
\text { lower boundary }\end{array}$ & ${ }^{\circ} \mathrm{K}$ & 17,957 \\
\hline $\begin{array}{l}T_{\mathrm{AH}} \text {, Rate of decrease at } \\
\text { upper boundary }\end{array}$ & ${ }^{\circ} \mathrm{K}$ & 6005 \\
\hline
\end{tabular}


against the ultimate size estimated with the analysis of age obtained from animals collected in the field. Data of this validation exercise are presented in Appendix A.

\section{Statistical analysis}

Data from DEB models (i.e. fitness variables) were analysed to test the null hypothesis that there is no difference in fitness of $B$. pharaonis between subtidal and intertidal habitats across all sectors (Fig. 1) of the study area using a two-way analysis of variance (ANOVA). The 26 sites were grouped into eight sectors to examine the null hypothesis that variability between sectors was greater than that within a sector; is that sites would cluster based on proximity. Thus, habitat (Hab; two levels) and sector (Sect; eight levels) were treated as fixed factors in the analysis. Sites per sector were replicates in the analysis; this implied that our design was unbalanced [i.e. having different numbers of replicates (i.e. $=$ sites)] within the groups or cells. This made tests less robust to heterogeneity of variances within groups (tested a priori by the Cochran's $C$ test). The Student-Newman-Keuls (SNK) test allowed the appropriate means comparison. When no homogeneous variances were rendered with any type of transformation such as in the case of two fitness variables (RE and ROB; Table 2), the significance level was set at 0.01 instead of 0.05 , as ANOVA can withstand variance heterogeneity, reducing the possibility of a Type I error (Ruiz et al., 2010).

To verify the amount of corrected occurrences predicted by DEB models of mussels, we adopted the Manel et al. (2001) method. We estimated the Sensitivity Index (\%, proportion of true presences correctly predicted

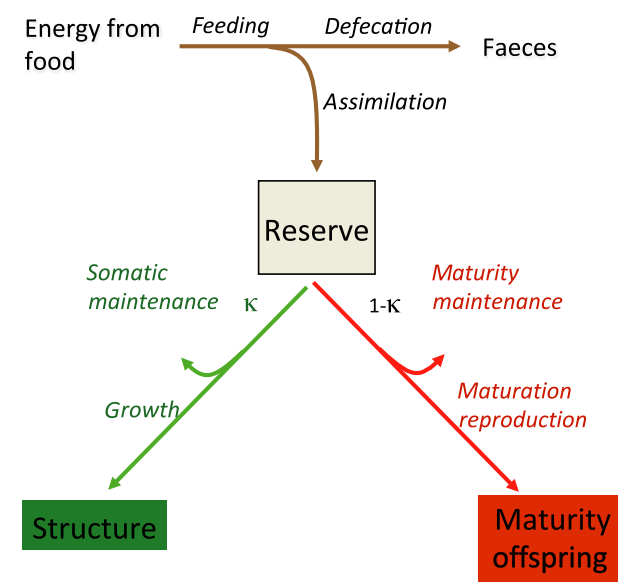

Figure 2 Schematic representation of the $\kappa$-rule Dynamic Energy Budget (DEB) model. A portion of ingested material is assimilated (absorbed) and indigestible material is lost as faeces. Assimilated products enter the reserve compartment. A fixed fraction $(\kappa)$ of flux from the reserves is spent on maintenance and growth (with maintenance as the priority), the remainder goes to maturity (for embryos and juveniles), reproduction (for adults) and maturity maintenance (from Kooijman, 2010, modified). throughout the 26 sites of this study) and the Specificity Index (\%, proportion of true absences correctly predicted throughout the 26 sites of this study). Model performance (\% true) was tested combining the first two metrics by calculating the percentage of all cases that were correctly predicted (true presences plus true absences divided by total cases). For this analysis, we made the simplifying assumption that reproductive failure could be considered as equivalent to species absence. This assumption is likely to be violated in populations that serve as genetic sinks (such as was predicted to occur in intertidal populations). However, this assumption allowed us to generate a more rigorous test of model predictions beyond what would have been possible using only presence data. In cases where the information was not present, we could not apply the analysis, and thus we considered those cases as not applicable (n.a.). Sensitivity analysis results are reported in Appendix 2 (Fig B1, Table B1). Statistical analyses were performed by PRIMER 6 (Anderson, 2001) and Statistica 6.0 (StatSoft, Inc., Tulsa, OK, USA).

\section{RESULTS}

Mussels experienced a broader range of BTs in intertidal (Fig. 3a) than subtidal (Fig. 3b; from values $<0{ }^{\circ} \mathrm{C}$ in winter to values higher than $45-50{ }^{\circ} \mathrm{C}$ in summer throughout the study area) although the overall subtidal mean BT was higher than intertidal BT by about $0.6-1.0{ }^{\circ} \mathrm{C}$; southern sectors (Ionian, Southern Tyrrhenian and Strait of Sicily) showed higher BT than northern according to a latitudinal gradient. The feeding time in the intertidal zone was more than $80 \%$ lower than in the subtidal due to the emersion times which had repercussions for the hourly amount of food available for animals. Consequently, under subtidal conditions food density was significantly higher than in the intertidal (more than $80 \%$ of difference; Fig. 4). Food density was higher in the Northern Adriatic and in the Gulf of Gabes than in Southern sites (Ionian and Tyrrhenian) where water masses were almost ultra-oligotrophic (CHL$a<0.1 \mu \mathrm{g}^{-1}$ ) throughout the study years. As a main consequence, not surprisingly, estimated fitness of the Pharaonic mussel throughout the study area was significantly higher under subtidal than intertidal conditions. For example, the infinite total length potentially reachable under subtidal conditions was more than two times larger than that reachable under intertidal conditions (ANOVA, $P<0.05$; Table 2; Fig. 5a). The same was true for the amount of eggs produced per life span (Fig. 5c,d) largely because the time to maturation (Fig. 5b) was much longer under intertidal conditions. Under intertidal conditions, the estimated gamete production per reproductive event was negligible or null (ANOVA, $P<0.05$; Fig. 5d) as compared to subtidal conditions. Fitness of Brachidontes was generally several times higher, both under subtidal and intertidal conditions (ANOVA $P>0.05$ ), in the Northern Adriatic and Strait of Sicily (Table 2; Fig. 6a-d) than other simulated sectors. 
Table 2 ANOVA performed on fitness response variables to test the difference between habitat (subtidal versus intertidal), sectors (see Fig. 1) and their interaction

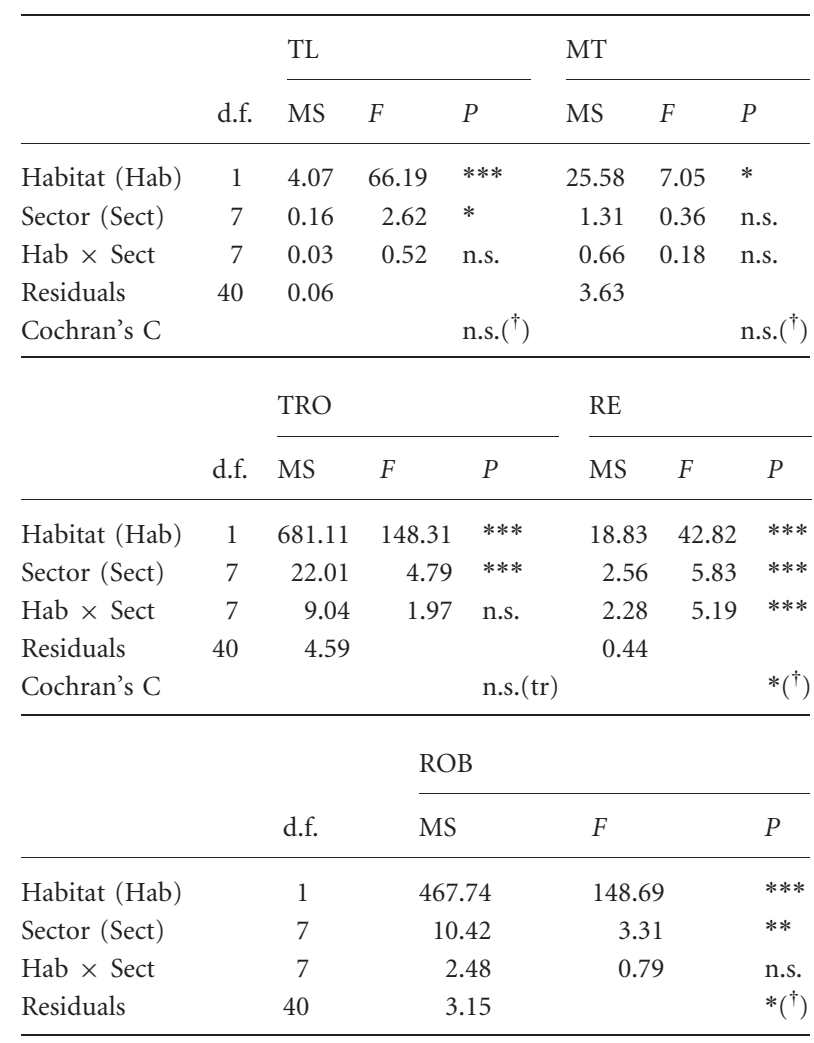

$\mathrm{TL}, \mathrm{cm}=$ total length; $\mathrm{TW}=$ total weight, $\mathrm{g} ; \mathrm{MT}=$ maturation time, days; $\mathrm{TRO}=$ total reproductive output as expressed by total amount of eggs emitted in 4 years; $\mathrm{RE}=$ number of reproductive events in 4 years; $\mathrm{ROB}=$ reproductive output per bout; n.s. $=$ not significant difference.

$* P<0.05 ; * * P<0.01 ; * * * P<0.001$

$\dagger$ Data log-transformed $[\ln (x+1]$.

\section{DISCUSSION}

The ability to predict the potential permissible habitat where an invasive species may be able to find suitable environmental conditions that permit persistence via continual reproduction is highly significant in a context of biological invasions. Apart from very large-scale experiments and surveys (e.g. Wethey et al., 2011) which are often very expensive, to date, there have been few reliable tools to predict, across broad spatial and temporal scales $(>10-50 \mathrm{~km}$ and $>1$ year), the potential reproductive output of marine invasive species. For example, classical correlative species distribution models which are mostly based on Geographic Information Systems (GIS) data are unable to predict sublethal responses, especially in novel environments (Hampe, 2004). While these models are able to provide qualitative indications of where habitat conditions should allow the presence of a certain species (Kearney, 2012), they do not produce direct, spatially explicit information on whether conditions in new environments will probably allow species reproduction, because

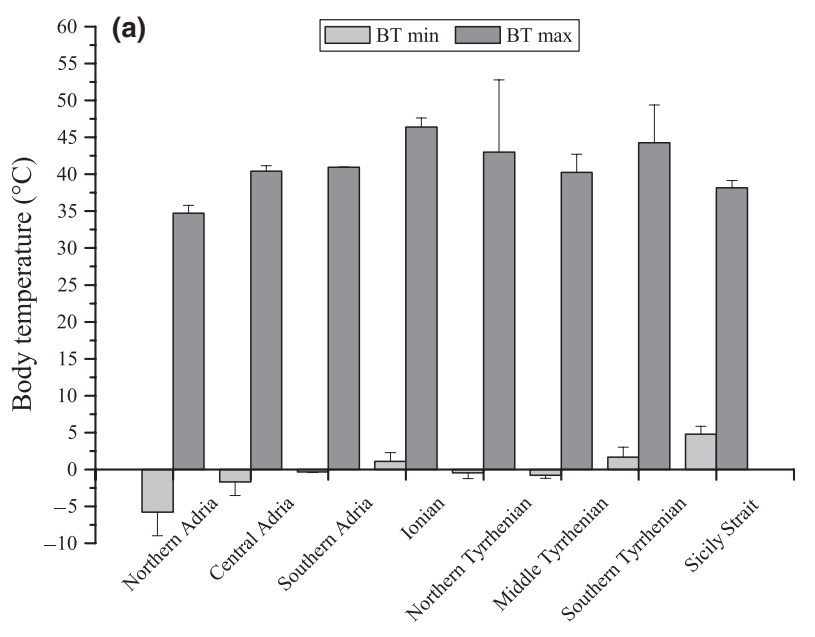

Sector

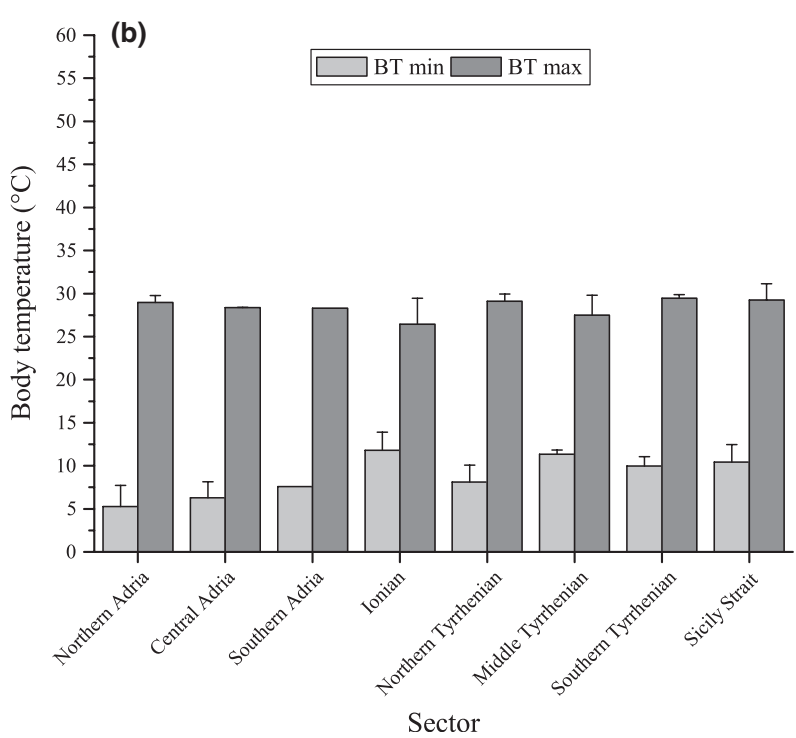

Figure 3 Maximum and minimum body temperatures throughout the study area under (a) intertidal conditions and (b) subtidal conditions.

predictions are based only on presence and absence. These approaches therefore cannot predict the presence, absence or change in the number of 'stepping stones' which may be a key to metapopulation dynamics (Leibold, 2009). Moreover, because they are generally based on environmental correlates at a species existing (realized niche) distribution, they may not be particularly effective when examining species with rapidly changing distributions, such as invasive species (Jeschke \& Strayer, 2008; Kearney et al., 2008).

Specifically, in biological invasion science, a critical factor in determining the success of an invasive species is understanding its ability to tolerate new environmental conditions and to identify features of the habitat that meet its requirements (Galil, 2008). Our mechanistic models, based on the study of eco-physiological tolerance limits and on the functional traits of the fundamental niche (Kearney et al., 2010), enabled an assessment of the factors involved in Brachidontes distribution and potential spread. 


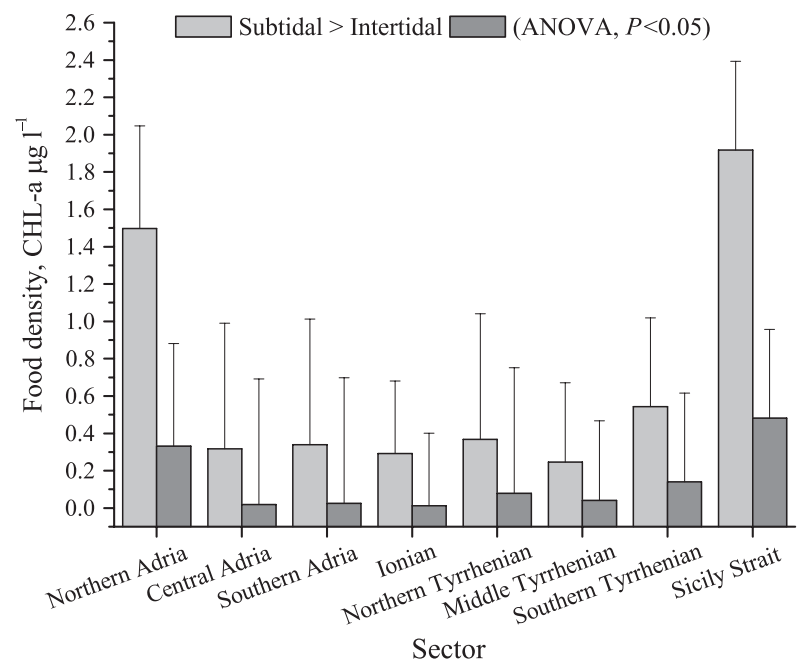

Figure 4 Amount of chlorophyll- $a$ throughout the study area both under subtidal and intertidal conditions.

Many studies (mostly indirect and rarely successful; sensu Simberloff, 2009) have tried to provide estimates of gamete pressure from correlated and measured variables (e.g. Schneider et al., 1998; Colautti et al., 2003; Semmens et al., 2004) to infer the distribution of invasive species. Nevertheless, if the factors of a successful colonization are: (1) the number of larvae/propagules produced by source populations, (2) temporal and spatial patterns of larval dispersal and delivery and (3) the ability of larvae to settle, survive and successfully colonize habitats, then mechanistic models like DEB seem to be a good candidate to predict many parameters associated with invasion success. The accurate prediction of number of eggs per life span combined with the number of RE per every site should help in understanding more about possible strategies to be adopted in mitigating biological invasions (Simberloff, 2009), especially when combined with information on dispersal and species interactions.

\section{Habitat preference of Brachidontes pharaonis in the Central Mediterranean}

Some important aspects emerged from our mechanistic analysis of the B. pharaonis fundamental niche: (1) in the Central Mediterranean conditions are generally suitable for B. pharaonis, (2) the main larval reservoir of this species is in subtidal habitat and (3) intertidal habitats appear to serve as sinks for larvae coming from subtidal habitats.

These findings are significant as this species has been always considered an intertidal organism by past research (e.g. Safriel \& Sasson-Frostig, 1988) with the implicit presumption that the main gamete source should be in the intertidal zone. Our findings are corroborated indirectly by Rilov et al. (2004) who found most B. pharaonis along the
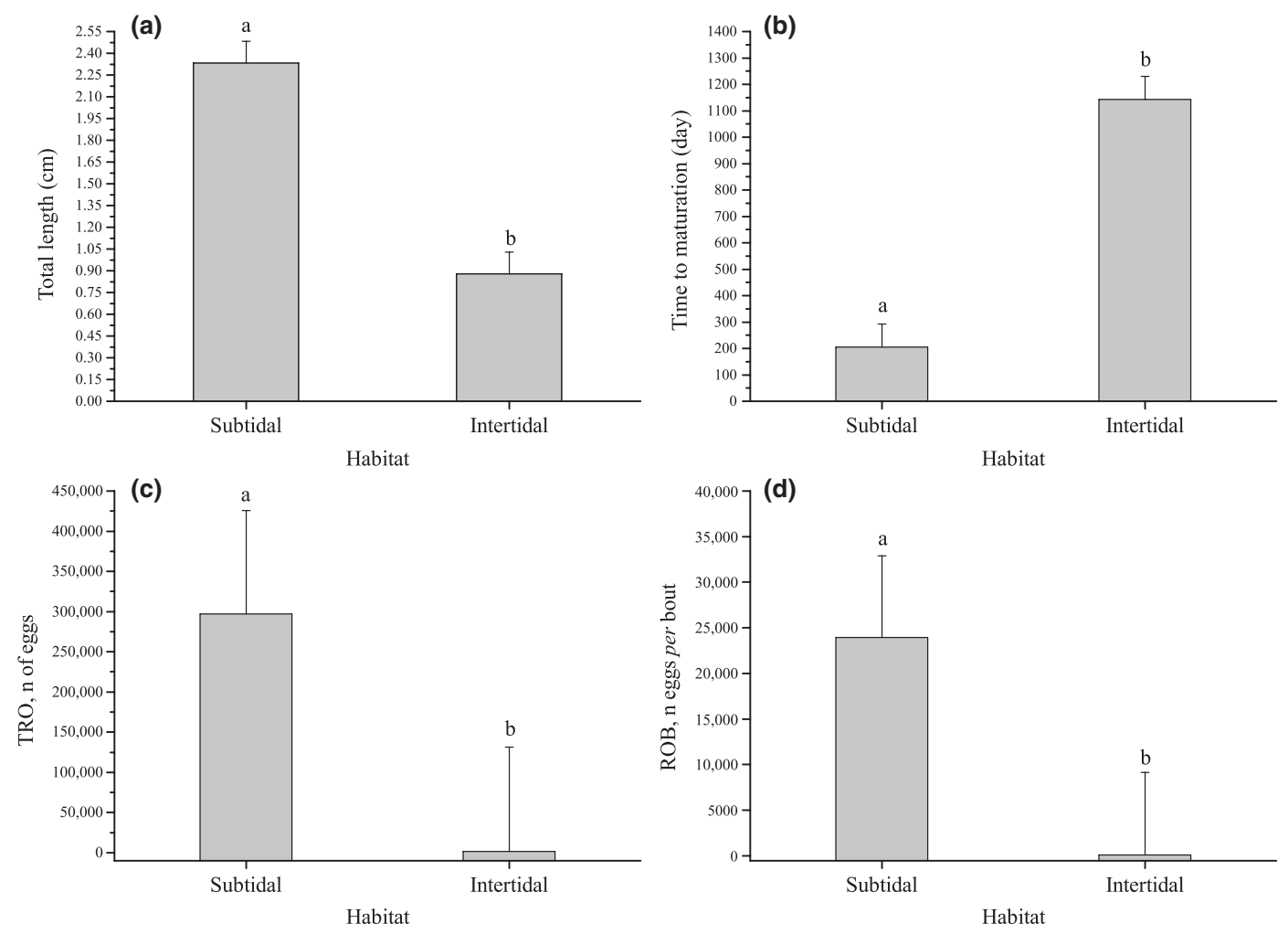

Figure 5 Fitness variables as a function of the habitat (upper left $=$ total length, $\mathrm{cm}$; upper right $=$ Time to maturation, day; bottom left $=$ Total Reproductive Output [TRO], $n$ of eggs; bottom right $=$ Reproductive Output per every Bout $[\mathrm{ROB}], n$ eggs per bout). 

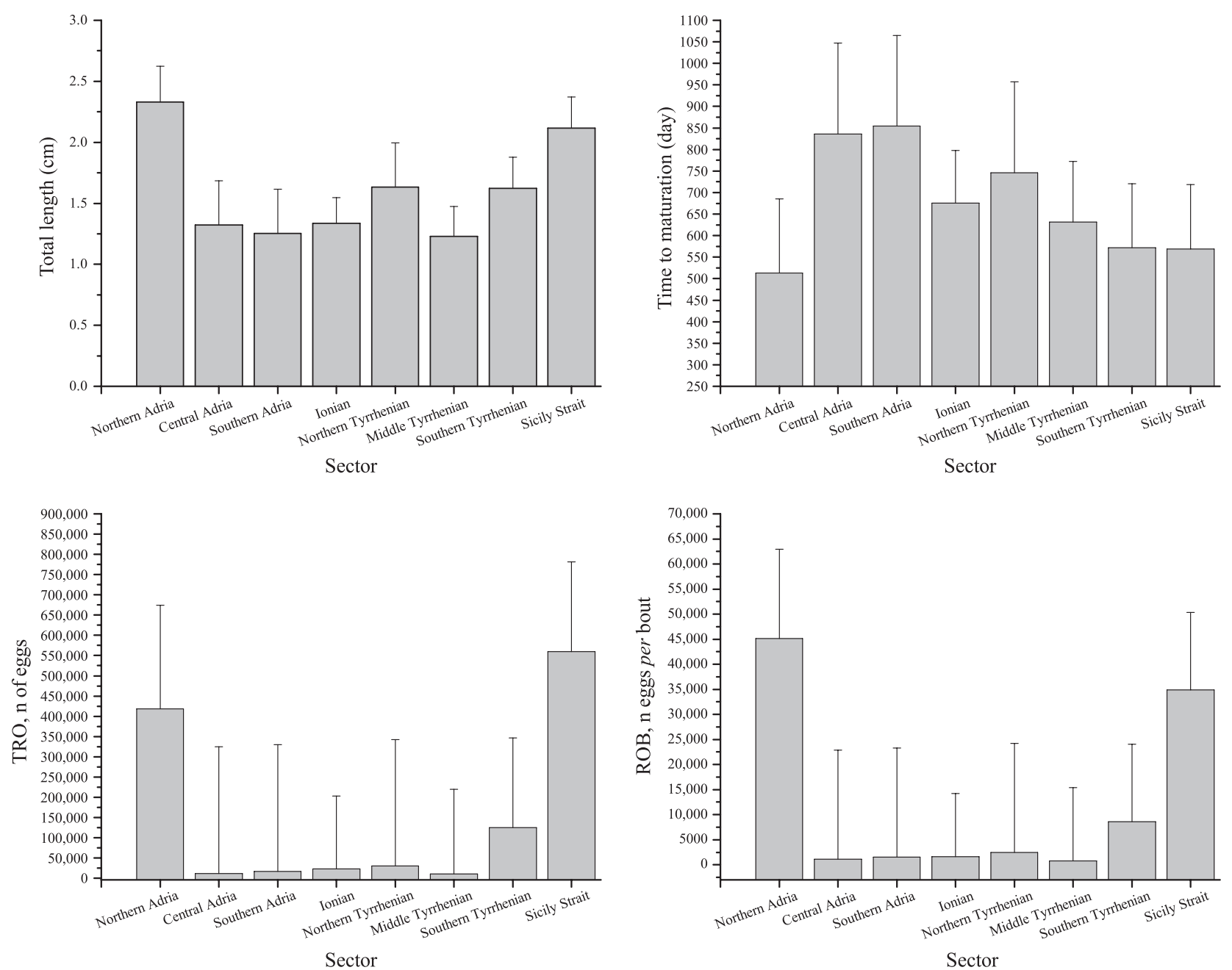

Figure 6 Fitness variables as a function of the habitat (upper left = total length, $\mathrm{cm}$; upper right = Time to maturation, day; bottom left $=$ Total Reproductive Output [TRO], $n$ of eggs; bottom right $=$ Reproductive Output per every Bout [ROB], $n$ eggs per bout).

Israeli coasts lower in the intertidal or on submerged hard substrate, as well as by Cilia \& Deidun (2012) who reported similar results for Malta populations. Our previous observations in western Sicily also confirmed this result. Sarà et al. (2000, 2008) found higher densities of Pharaonic mussels below the low tide lower mark than on intertidal surfaces and more recently, Garaventa et al. (2012) reported this species from lower mid-littoral artificial surfaces of industrial plants of Southern Sicily (Siracusa and Augusta).

Such findings are in theoretical contrast with what Mediterranean intertidal characteristics might superficially suggest. Here, intertidal conditions may be usually considered less harsh than those of oceans such as the Northern Atlantic (Sarà et al., 2007) or along the Pacific coasts of North America (Helmuth et al., 2006), where wave forces can be much greater and tidal ranges greater. Mediterranean tides indeed are smaller in amplitude than in these regions (a few decimetres as opposed to several metres). Nevertheless, in oceanic habitats, larger tidal amplitudes are often associated with water masses that may be trophically richer with large amounts of suspended food for intertidal filter feeders like along the Pacific of North America or the Southern Iceland where suspended chlorophyll-a concentrations have spikes of over than $30 \mathrm{~g}^{-1}$ (e.g. Petes et al., 2007; Sarà et al., 2007). Subsequently, although the intertidal feeding time in midintertidal zones is often not more than $50 \%$ of the total time in more oceanic regimes, at the re-immersion at high tide, organisms can rely on large amounts of food. In the Central Mediterranean, although overall the intertidal feeding time is greater than that of oceanic coasts worldwide (more than $80 \%$ ), at the re-immersion at low tide, animals rely on water masses that are nearly oligotrophic, with less $0.5 \mu \mathrm{g} \mathrm{l^{-1 }}$ in many sites throughout the study area examined here. Thus, even given the small amplitude of tides in the Mediterranean, food levels are sufficiently depauperate that reduced feeding time leads to reproductive failure. Therefore, under intertidal conditions, Brachidontes need to cope with highly variable BTs closer to thermal tolerance limits (Sarà et al., 2011) and scant food to compensate those intertidal thermal conditions. 


\section{Predicting future patterns of colonization}

Our results suggest that intertidal life for B. pharaonis along the central coasts of the Mediterranean is suboptimal for this species. DEB showed the largest fitness of B. pharaonis in (1) the Northern Adriatic (De Min \& Vio, 1997; but see Appendix B for sensitivity analysis) where water masses are largely influenced by large terrigenous-continental inputs from Po River, (2) in the most polluted areas of the Mediterranean, the Gulf of Gabes and Augusta, (3) in the trophically enriched waters of the saltpan system in the western Sicily (Sarà et al., 2000) and around Malta (Cilia \& Deidun, 2012).

Such an insight is consistent with first records of $B$. pharaonis in western Mediterranean. It was first recorded on the shores of Malta (Lanfranco, 1975) and Southern-east Sicily, Augusta and Catania (Di Geronimo, 1971), then recorded in western Sicily (Sarà et al., 2000) and successively in other northern sites (Zangara, 2007). Thus, our results are consistent with the likely entrance routes of this invasive species in the western Basin. This is crucial finding for the accuracy of our mechanistic approach and represents an important indirect validation which further supports the validation exercise carried out experimentally in the Stagnone di Marsala (Appendix 1A).

This also implies that, in theory, B. pharaonis should be able to survive anywhere in the western Basin provided a mechanism of larval dispersal. Brachidontes pharaonis is indeed reported as an organism able to move through the Mediterranean by ship transportation through ballast waters or as a fouler of ship keels (Shefer et al., 2004; Sirna-Terranova et al., 2006; Occhipinti-Ambrogi et al., 2010). Consequently, the speed of colonization by this mechanism and its ability to reach novel environments throughout the western Mediterranean basin should be limited to ships carrying larvae to coastal areas far from the points of origin (e.g. Augusta harbour, Gulf of Gabes or Malta). Nevertheless, once a significant flux of larvae reaches any hard substrata in the central Mediterranean, they could substantially establish a population able to reproduce and persist over time. Subtidal populations in new locations should thereby work as a source to assure sufficient larvae to diminish the impacts of environmental and demographic stochasticities during colonization of new sites. Such a fact should enhance the likelihood that an initial introduction would establish on-going populations (e.g. MacArthur \& Wilson, 1967) in sites far from where gametes are produced (Simberloff, 2009).

In conclusion, while at present stage, there is not sufficient theory and research to derive insights on how biotic relationships may quantitatively affect niche dimensions (according to the concept of realized niche; sensu Hutchinson, 1957), this DEB exercise successfully provides a means of estimating the fundamental niche of this species and thus identify where it could potentially colonize (sensu Kearney and Porter 2009). Our approach was able to investigate, in a mechanistic way and through a very limited number of simple para- meters (cf. Kearney, 2012), the ability of B. pharaonis to exploit energy from food (Sarà et al., 2011, 2012) under both subtidal and intertidal conditions throughout the Central Mediterranean Sea. This mechanistic approach, which has been already used with success in terrestrial habitats with lizards (Kearney, 2012) and for Mytilid mussels (Kearney et al., 2010; Sarà et al., 2011, 2012), crustaceans and fish (Jusup et al., 2011; Pecquerie et al., 2011), seems a good candidate to predict distributions of invasive organisms starting from their functional traits and from a few mechanistic rules (Kooijman, 2010). This information will be important when assessing the future potential expansion of invasive species under conditions of future warming in the Mediterranean Sea, as a result of global climate change (Sarà et al., in pressa), where tropical thermo-tolerant invasive species may have distinct advantage over native species, affecting global patterns of biodiversity.

\section{ACKNOWLEDGEMENTS}

This paper has been sustained by INTERMED, one of the CIRCLE Med projects funded by EU in the framework of Circle ERA Net project (which is funded by the European Commission 6th Framework Programme). This research was in part funded to G.S. and B.H. by a Visiting Scholar Award made by the Office of the Provost at the University of South Carolina. We thank all collaborators and students from EEB lab at UNIPA. We are especially grateful to Mike Kearney to have addressed our effort in DEB modelling, providing us the first Excel routine to run DEB models, John Widdows to have allowed the fine tuning of our experimental lab work to measure eco-physiological variables in bivalves.

\section{REFERENCES}

Anderson, M.J. (2001) A new method for non-parametric multivariate analysis of variance. Austral Ecology, 26, 32-46.

Beukema, J.J., Dekker, R. \& Jansen, J.M. (2009) Some like it cold: populations of the tellinid bivalve Macoma balthica (L.) suffer in various ways from a warming climate. Marine Ecology Progress Series, 384, 135-145.

Chemello, R. \& Silenzi, S. (2011) Vermetid reefs in the Mediterranean Sea as archives of sea-level and surface temperature changes. Chemistry and Ecology, 27, 121-127.

Cilia, D. \& Deidun, A. (2012) Branching out: mapping the spatial expansion of the Lessepsian invader mytilid Brachidontes pharaonis (Fischer, 1870) around the Maltese Islands. Marine Biodiversity Records, 5, 1-8.

Colautti, R.I., Niimi, A.J., van Overdijk, C.D.A., Mills, E.L., Holeck, K. \& MacIsaac, H.J. (2003) Spatial and temporal analysis of transoceanic shipping vectors to the Great Lakes. Invasive species: vectors and management strategies (ed. by G.M. Ruiz and J.T. Carlton), pp. 227-246. Island Press, Washington, DC. 
De Min, R. \& Vio, E. (1997) Molluschi conchiferi del litorale sloveno. Annals for Istrian and Mediterranean Studies, Koper, Historia Naturalis, 11, 241-258.

Di Geronimo, I. (1971) Prima segnalazione nelle coste italiche di Brachidontes variabilis (Krauss). Bollettino dell'Accademia Gioenia di Scienze Naturali di Catania, 10, 847-852.

Dong, Y.W., Wang, H.S., Han, G.D., Ke, C.H., Zhan, X., Nakano, T. \& Williams, G.A. (2012) The impact of Yangtze River discharge, ocean currents and historical events on the biogeographic pattern of Cellana toreuma along the China Coast. PLoS ONE, 7, e36178.

Galil, B.S. (2007) Seeing Reed: alien species along the Mediterranean coast of Israel. Aquatic Invasions, 2, 281-312.

Galil, B.S. (2008) Alien species in the Mediterranean Sea-which, when, where, why? Hydrobiologia, 606, 105-116.

Garaventa, F., Corrà, C., Piazza, V., Giacco, E., Greco, G., Pane, L. \& Faimali, M. (2012) Settlement of the alien mollusc Brachidontes pharaonis in a Mediterranean industrial plant: bioassays for antifouling treatment optimization and management. Marine Environmental Research, 76, 90-96.

Hampe, A. (2004) Bioclimate envelope models: what they detect and what they hide. Global Ecology and Biogeography, 13, 469-476.

Helmuth, B. (1998) Intertidal mussel microclimates: predicting the body temperature of a sessile invertebrate. Ecological Monographs, 68, 51-74.

Helmuth, B., Broitman, B.R., Blanchette, C.A., Gilman, S., Halpin, P., Harley, C.D.G., O'Donnel, M.J., Hofmann, G.E., Menge, B. \& Stricklan, D. (2006) Mosaic patterns of thermal stress in the rocky intertidal zone: implications for climate change. Ecological Monographs, 76, 461-479.

Helmuth, B., Yamane, L., Lalwani, S., Matzelle, A., Tockstein, A. \& Gao, N. (2011) Hidden signals of climate change in intertidal ecosystems: what (not) to expect when you are expecting. Journal of Experimental Marine Biology and Ecology, 400, 191-199.

Hughes, T.P., Bellwood, D.R., Folke, C., Stenek, R.S. \& Wilson, J. (2005) New paradigms for supporting the resilience of marine ecosystems. Trends in Ecology \& Evolution, 20, 380-386.

Hutchinson, G.E. (1957) Concluding remarks. Cold Spring Harbor Symp. Quantitative Biology, 22, 415-427.

Jeschke, J. \& Strayer, D. (2008) Usefulness of bioclimatic models for studying climate change and invasive species. Annals of the New York Academy of Sciences, 1134, 1-24.

Jusup, M., Klanjscek, T., Matsuda, H. \& Kooijman, S.A.L.M. (2011) A full lifecycle bioenergetic model for bluefin tuna. PLoS ONE, 6, e21903.

Kearney, M. (2012) Metabolic theory, life history and the distribution of a terrestrial ectotherm. Functional Ecology, 26, 167-179.

Kearney, M. \& Porter, W.P. (2009) Mechanistic niche modelling: combining physiological and spatial data to predict species' ranges. Ecology Letters, 12, 334-350.

Kearney, M., Phillips, B.L., Tracy, C.R., Christian, K.A., Betts, G. \& Porter, W.P. (2008) Modelling species distributions without using species distributions: the cane toad in Aus- tralia under current and future climates. Ecography, 31, 423-434.

Kearney, M., Simpson, S.J., Raubenheimer, D. \& Helmuth, B. (2010) Modelling the ecological niche from functional traits. Philosophical Transactions of the Royal Society B: Biological Sciences, 365, 3469-3483.

Kearney, M.R., Matzelle, A. \& Helmuth, B. (2012) Biomechanics meets the ecological niche: the importance of temporal data resolution. The Journal of Experimental Biology, 215, 922-933.

Kooijman, S.A.L.M. (2010) Dynamic energy budget theory for metabolic organisation, 3rd edn. Cambridge University Press, Cambridge.

Lanfranco, G. (1975) The Brachidontes variabilis (Krauss) (Mollusca, Bivalvia, Mytilidae) in Malta. The Maltese Naturalist, 2, 27.

Leibold, M.A. (2009) Spatial and metacommunity dynamics in biodiversity. The Princeton guide to ecology (ed. by S.A. Levin), pp. 312-319. Princeton University Press, Princeton \& Oxford.

Lika, K., Kearney, M.R. \& Kooijman, S.A.L.M. (2011) The "covariation method" for estimating the parameters of the standard Dynamic Energy Budget model II: properties and preliminary patterns. Journal of Sea Research, 66, 278-288.

Lima, F.P., Burnett, N.P., Helmuth, B., Kish, N., AveniDeforge, K. \& Wethey, D.S. (2011) Monitoring the intertidal environment with biomimetic devices. Biomimetic based applications (ed. by M. Cavrak), pp. 499-522. InTech, ISBN: 978-953-307-195-4. Available at: http://www.intechopen. com/books/biomimetic-based-applications/monitoring-theintertidal-environment-with-biomimetic-devices (accessed 6 March 2013).

MacArthur, R.H. \& Wilson, E.O. (1967) The theory of island biogeography. Princeton University Press, Princeton, NJ.

Manel, S., Williams, H.C. \& Ormerod, S.J. (2001) Evaluating presence-absence models in ecology: the need to account for prevalence. Journal of Applied Ecology, 38, 921-931.

McQuaid, C.D. \& Phillips, T.E. (2006) Mesoscale variation in reproduction, recruitment and population structure of intertidal mussels with low larval input: a bay/open coast comparison. Marine Ecology Progress Series, 327, 193-206.

Menge, B.A. \& Olson, A.M. (1990) Role of scale and environmental factors in regulation of community structure. Trends in Ecology and Evolution, 5, 52-57.

Mislan, K.A.S., Blanchette, C.A., Broitman, B.R. \& Washburn, L. (2011) Spatial variability of emergence, splash, surge, and submergence in wave-exposed rocky-shore ecosystems. Limnology and Oceanography, 56, 857-866.

Monaco, C.J. \& Helmuth, B. (2011) Tipping points, thresholds, and the keystone role of physiology in marine climate change research. Advances in Marine Biology, 60, 123-160.

Occhipinti-Ambrogi, A., Marchini, A., Cantone, G., Castelli, A., Chimenz, C., Cormaci, M., Froglia, C., Furnari, G., Gambi, M.C., Giaccone, G., Giangrande, A., Gravili, C., Mastrototaro, F., Mazziotti, C., Orsi-Relini, L. \& Piraino, 
S. (2010) Alien species along the Italian coasts: an overview. Biological Invasions, 13, 215-237.

O'Connor, M.I., Bruno, J.F., Gaines, S.D., Halpern, B.S., Lester, S.E., Kinlan, B.P. \& Weiss, J.M. (2007) Temperature control of larval dispersal and the implications for marine ecology, evolution, and conservation. Proceedings of the National Academy of Sciences USA, 104, 1266-1271.

Palmeri, V. (2011) Ecological responses by marine filter feeders as a function of variability scales induced by anthropogenic pressures, pp. 140. PhD Dissertation, Università di Palermo, Palermo, Italy (in Italian)

Pecquerie, L., Johnson, L.R., Kooijman, S.A.L.M. \& Nisbet, R.M. (2011) Analyzing variations in life-history traits of Pacific salmon in the context of dynamic energy budget (DEB) theory. Journal of Sea Research, 66, 424-433.

Peharda, M., Ezgeta-Balic, D., Radman, M., Sinjkevic, N., Vrgoc, N. \& Isajlovic, I. (2012) Age, growth and population structure of Acanthocardia tuberculata (Bivalvia: Cardiidae) in the eastern Adriatic Sea. Scientia Marina, 76, 59-66.

Petes, L.E., Menge, B.A. \& Murphy, G.D. (2007) Environmental stress decreases survival, growth, and reproduction in New Zealand mussels. Journal of Experimental Marine Biology and Ecology, 351, 83-91.

Pusceddu, A., Sarà, G., Mazzola, A. \& Fabiano, M. (1997) Relationships between suspended and sediment organic matter in a semi-enclosed marine system: the Stagnone di Marsala sound (Western Sicily). Water, Air and Soil Pollution, 99, 343-352.

Rilov, G., Benayahu, Y. \& Gasith, A. (2004) Prolonged lag in population outbreak of an invasive mussel: a shifting habitat model. Biological Invasions, 6, 347-364.

Roff, D.A. (1992) The evolution of life histories: theory and analysis. Chapman and Hall, New York.

Ruiz, J.M., Marco-Mendez, C. \& Sanchez-Lizaso, J.L. (2010) Remote influence of off-shore fish farm waste on Mediterranean seagrass (Posidonia oceanica) meadows. Marine Environmental Research, 69, 118-126.

Safriel, U.N. \& Sasson-Frostig, Z. (1988) Can colonizing mussel outcompete indigenous mussel? Journal of Experimental Marine Biology and Ecology, 117, 211-226.

Sarà, G. (2006) Hydrodynamic effect on the origin and quality of organic matter for bivalves: an integrated isotopic, biochemical and transplant study. Marine Ecology Progress Series, 328, 65-73.

Sarà, G. (2009) Variation of suspended and sedimentary organic matter with depth in shallow coastal waters. Wetlands, 29, 1234-1242.

Sarà, G. \& De Pirro, M. (2011) Heart beat rate of invasive Brachidontes pharaonis with respect to the native Mytilaster minimus within the Mediterranean Sea at varying salinities. Italian Journal of Zoology, 78, 193-197.

Sarà, G., Romano, C., Caruso, M. \& Mazzola, A. (2000) The new Lessepsian entry Brachidontes pharaonis (Fischer P, 1870) (Bivalvia, Mytilidae) in the western Mediterranean: a physiological analysis under varying natural conditions. Journal of Shellish Research, 19, 967-977.
Sarà, G., Vizzini, S. \& Mazzola, A. (2003) Sources of carbon and dietary habits of new Lessepsian entry Brachidontes pharaonis (Bivalvia, Mytilidae) in the western Mediterranean. Marine Biology, 143, 713-722.

Sarà, G., De Pirro, M., Romano, C., Rumolo, P., Sprovieri, M. \& Mazzola, A. (2007) Sources of organic matter for intertidal consumers in Ascophyllum-shores (Sw Iceland): a multi stable isotope approach. Helgoland Marine Research, 61, 297-302.

Sarà, G., Romano, C., Widdows, J. \& Staff, F.J. (2008) Effect of salinity and temperature on feeding physiology and scope for growth of an invasive species (Brachidontes pharaonis Mollusca: Bivalvia) within the Mediterranean Sea. Journal of Experimental Marine Biology and Ecology, 363, 130-136.

Sarà, G., Kearney, M. \& Helmuth, B. (2011) Combining heat-transfer and energy budget models to predict local and geographic patterns of mortality in Mediterranean intertidal mussels. Chemistry and Ecology, 27, 135-145.

Sarà, G., Reid, G., Rinaldi, A., Palmeri, V., Troell, M. \& Kooijman, S.A.L.M. (2012) Growth and reproductive simulation of candidate shellfish species at fish cages in the southern Mediterranean: dynamic Energy Budget (DEB) modelling for integrated multi-trophic aquaculture. Aquaculture, 324-325, 259-266.

Sarà, G., Milanese, M., Prusina, I., Sarà, A., Angel, D.L., Glamuzina, B., Nitzan, T., Freeman, S., Rinaldi, A., Palmeri, V., Montalto, V., Lo Martire, M., Gianguzza, P., Arizza, V., Lo Brutto, S., De Pirro, M., Helmuth, B., Murray, J., De Cantis, S. \& Williams, G.A. (in press-a) The impact of climate change on Mediterranean intertidal communities: losses in coastal ecosystem integrity and services. Regional Environmental Change, doi: 10.1007/s10113-012-0360-z.

Sarà, G., Palmeri, V., Montalto, V., Rinaldi, A. \& Widdows, J. (in press-b) The parameterisation of bivalve functional traits in a context of mechanistic ecophysiological Dynamic Energy Budget models. Marine Ecology Progress Series, doi: 10.3354/meps10195.

Schneider, D.W., Ellis, C.D. \& Cummings, K.S. (1998) A transportation model assessment of risk to native mussel communities of zebra mussel spread. Conservation Biology, 12, 788-800.

Semmens, B.X., Buhle, E.R., Salomon, A.K. \& PattengillSemmens, C.V. (2004) A hotspot of non-native aquarium fishes: evidence for the aquarium trade as an invasion pathway. Marine Ecology Progress Series, 266, 239-244.

Shefer, S., Abelson, A., Mokady, O. \& Geffen, E. (2004) Red to Mediterranean Sea bioinvasion: natural drift through the Suez Canal, or anthropogenic transport? Molecular Ecology, 13, 2333-2344.

Simberloff, D. (2009) The role of propagule pressure in biological invasions. Annual Review of Ecology, Evolution, and Systematics, 40, 81-102.

Sirna-Terranova, M.S., Lo Brutto, S., Arculeo, M. \& Mitton, J.B. (2006) Population structure of Brachidontes pharaonis (P. Fischer, 1870) (Bivalvia, Mytilidae) in the Mediterranean Sea, and evolution of a novel mtDNA polymorphism. Marine Biology, 150, 89-101. 
Stearns, S.C. (1992) The evolution of life histories. Oxford University Press, Oxford.

Wethey, D.S., Brin, L.D., Helmuth, B. \& Mislan, K.A.S. (2011) Predicting intertidal organism temperatures with modified land surface models. Ecological Modelling, 222, 3568-3576.

Zangara, S. (2007) Study of bivalve distribution in the Western Sicilian coasts, pp. 78. Master's Degree Thesis, University of Palermo, Palermo, Italy (in Italian).

\section{BIOSKETCH}

Gianluca Sarà (Ph.D., 1994) is Associate Professor of Ecology at University of Palermo (Italy) and coordinates the Laboratory of Experimental Ecology of the Department of Ecology. He graduated for his $\mathrm{PhD}$ in 1994 at University of Messina (Italy) discussing a thesis dealing with bioenergetics and growth performance of cultivated bivalves in the Southern Mediterranean Sea. His research focuses on the effect of anthropogenic influence on ecosystems and the study of structures and ecosystem functioning through its influence on the rates of synthesis of biological structures, chemical compositions, energy and material fluxes, population processes, species interactions and thereby biodiversity.

Author contributions: G.S. conceived the idea, elaboration, led the writing and funding; V.P. and A.R. data collection and elaboration; V.M. collected the data, elaboration and writing; B.H. conceived the idea and writing.

Editor: Wilfried Thuiller

\section{APPENDIX A}

\section{Materials and Methods}

Throughout the 2009 and 2010, we collected more than 1000 animals from the saltpan of the close Stagnone di Marsala (Western Sicily, Italy) where this species has established highly dense populations (Sarà et al., 2000). We estimated the age through the analysis of shell rings proposed in Peharda et al. (2012) cutting shells by a Dremel rotary (Series 4000; Robert Bosch Tool Corporation Inc. Germany) and reading the number of rings through an stereomicroscope Leica Z4 (Leica Microsystems GmbH, Wetzlar, Germany).

\section{Results}

Brachidontes maximal length $(3.7 \mathrm{~cm}$, both in 2009 and 2010) was reached after 4 years in the field (Fig. A1), while that predicted by DEB under real environmental conditions was c. $3.9 \mathrm{~cm}$ at the end of 2009. DEB model estimates deviated from reality by c. $5.6 \%$ in 4 years (a yearly error of less than $c .1 .5 \%)$.

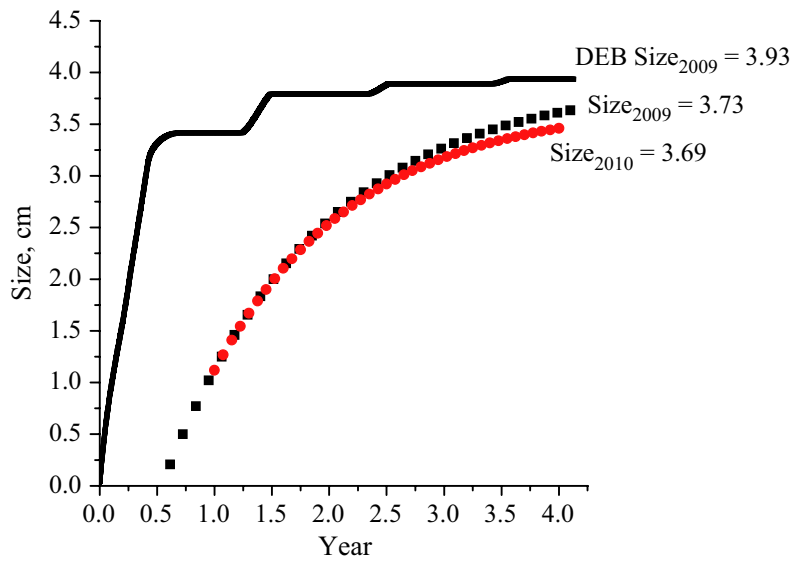

Figure A1 Age-size curves as estimated through the DEB and as validated (2009 and 2010) in the field through experimental procedures.

\section{APPENDIX B}

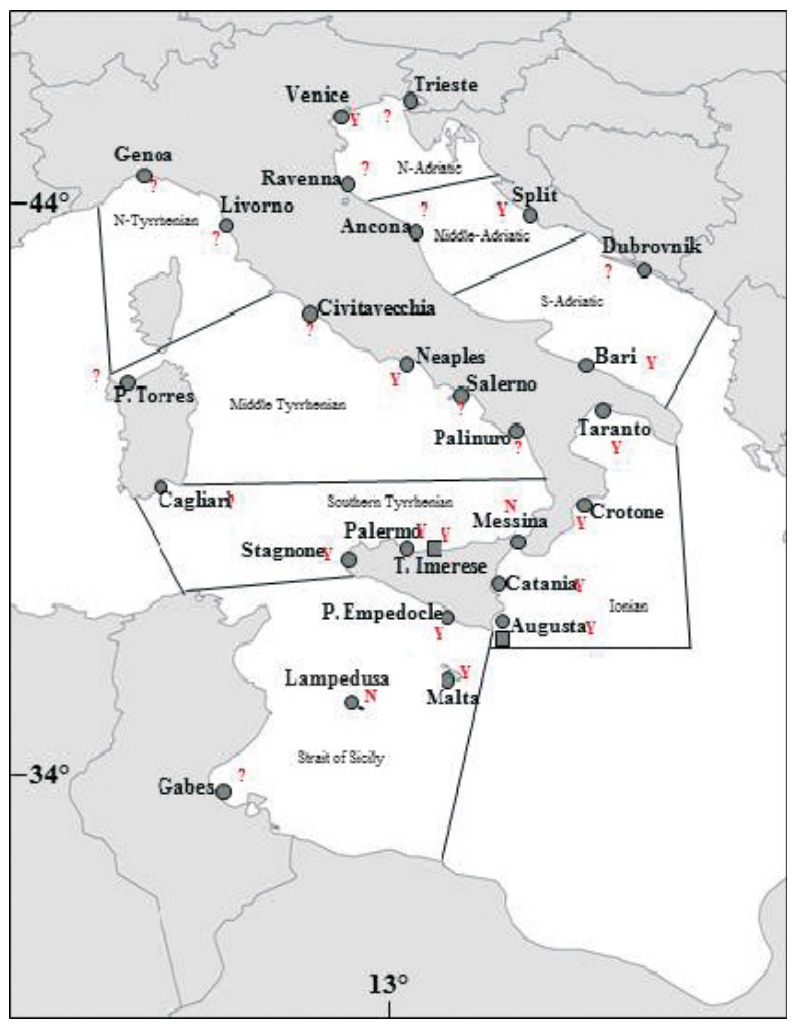

Figure B1 Map of all sites investigated in the present paper throughout the Central Mediterranean reporting presence $(\mathrm{Y})$, absence $(\mathrm{N})$ of Brachidontes pharaonis using data from literature or personal communications as reported in the table below. Presences/absences are indicated per single site. A question mark indicates the lack of information or suspects about the presence, but currently there is no evidence about it. 
G. Sarà et al.

Table B1 Brachidontes pharaonis: literature or personal communications reporting presence or absence of the species throughout study area

\begin{tabular}{|c|c|c|c|c|c|c|}
\hline Sector & Location & Occ & Author & Year & Title & Journal reference \\
\hline Northern Adria & Ravenna & $?$ & No record & - & - & - \\
\hline Northern Adria & Trieste & $?$ & De Min R, Vio E & 1997 & $\begin{array}{l}\text { Molluschi conchiferi } \\
\text { del litorale sloveno }\end{array}$ & $\begin{array}{l}\text { Ann Istran Med Stud, Koper, } \\
\text { Historia naturalis, 11, 241-258 }\end{array}$ \\
\hline Northern Adria & Venezia & $\mathrm{Y}$ & $\begin{array}{l}\text { G. Sarà, personal } \\
\text { communication }\end{array}$ & 2009 & & \\
\hline Central Adria & Ancona & $?$ & No record & - & - & - \\
\hline Central Adria & Split & $\mathrm{Y}$ & $\begin{array}{l}\text { G. Sarà, personal } \\
\text { communication }\end{array}$ & 2010 & & \\
\hline Southern Adria & Bari & $\mathrm{Y}$ & $\begin{array}{l}\text { G. Sarà, personal } \\
\text { communication }\end{array}$ & 2010 & & \\
\hline Southern Adria & Dubrovnik & $?$ & No record & - & - & - \\
\hline Ionian & Augusta & $\mathrm{Y}$ & Garaventa et al. & 2012 & $\begin{array}{l}\text { Settlement of the alien mollusc } \\
\text { Brachidontes pharaonis in a } \\
\text { Mediterranean industrial plant: } \\
\text { bioassays for antifouling treatment } \\
\text { optimization and management }\end{array}$ & $\begin{array}{l}\text { Marine Environmental Research, } \\
\text { 76, 90-96 }\end{array}$ \\
\hline Ionian & $\begin{array}{l}\text { Augusta } \\
\text { Power Plant }\end{array}$ & $\mathrm{Y}$ & Garaventa et al. & 2012 & $\begin{array}{l}\text { Settlement of the alien mollusc } \\
\text { Brachidontes pharaonis in a } \\
\text { Mediterranean industrial plant: } \\
\text { bioassays for antifouling treatment } \\
\text { optimization and management }\end{array}$ & $\begin{array}{l}\text { Marine Environmental Research } \\
\text { 76, 90-96 }\end{array}$ \\
\hline Ionian & Catania & $\mathrm{Y}$ & $\begin{array}{l}\text { G. Sarà, personal } \\
\text { communication }\end{array}$ & 2011 & & \\
\hline Ionian & Crotone & $\mathrm{Y}$ & $\begin{array}{l}\text { G. Sarà, personal } \\
\text { communication }\end{array}$ & 2011 & & \\
\hline Ionian & Messina & $\mathrm{N}$ & Cosentino et al. & 2009 & $\begin{array}{l}\text { The CSI of the Faro Coastal } \\
\text { lake (Messina): a natural } \\
\text { observatory for the incoming } \\
\text { of marine alien species }\end{array}$ & $\begin{array}{l}\text { Poster, } 40^{\circ} \text { Congresso della } \\
\text { Societá Italiana di Biologia } \\
\text { Marina }\end{array}$ \\
\hline Ionian & Taranto & $\mathrm{Y}$ & Crocetta et al. & 2009 & $\begin{array}{l}\text { New distributional and ecological } \\
\text { data of some marine alien molluscs } \\
\text { along the southern Italian coasts }\end{array}$ & $\begin{array}{l}\text { Marine Biodiversity } \\
\text { Records, 2, e23 }\end{array}$ \\
\hline Northern Tyrrhenian & Genova & $?$ & No record & - & - & - \\
\hline Northern Tyrrhenian & Livorno & $?$ & No record & - & - & - \\
\hline Middle Tyrrhenian & Civitavecchia & $?$ & No record & - & - & - \\
\hline Middle Tyrrhenian & Napoli & $\mathrm{Y}$ & Crocetta et al. & 2009 & $\begin{array}{l}\text { New distributional and ecological } \\
\text { data of some marine alien molluscs } \\
\text { along the southern Italian coasts }\end{array}$ & $\begin{array}{l}\text { Marine Biodiversity } \\
\text { Records, 2, e23 }\end{array}$ \\
\hline Middle Tyrrhenian & Palinuro & $?$ & No record & - & - & - \\
\hline Middle Tyrrhenian & Porto Torres & $?$ & No record & - & - & - \\
\hline Middle Tyrrhenian & Salerno & $?$ & No record & - & - & - \\
\hline Southern Tyrrhenian & Cagliari & $?$ & No record & - & - & - \\
\hline Southern Tyrrhenian & Palermo & $\mathrm{Y}$ & Terranova et al. & 2006 & $\begin{array}{l}\text { Population structure of Brachidontes } \\
\text { pharaonis (P. Fisher, 1870) (Bivalvia, } \\
\text { Mytilidae) in the Mediterranean Sea, } \\
\text { and evolution of a novel mtDNA } \\
\text { polymorphism }\end{array}$ & $\begin{array}{l}\text { Marine Biology, } \\
\text { 150, 89-101 }\end{array}$ \\
\hline Southern Tyrrhenian & $\begin{array}{l}\text { Stagnone } \\
\text { di Marsala }\end{array}$ & $\mathrm{Y}$ & Sarà et al. & 2000 & $\begin{array}{l}\text { The new lessepsian entry } \\
\text { Brachidontes pharaonis } \\
\text { (Fischer P., 1870) (Bivalvia, } \\
\text { Mytilidae) in the western } \\
\text { Mediterranean: a physiological } \\
\text { analysis under varying natural } \\
\text { conditions }\end{array}$ & $\begin{array}{l}\text { Journal of Shellfish } \\
\text { Research, 19, 967-977 }\end{array}$ \\
\hline
\end{tabular}


Predicting biological invasions in marine habitats

Table B1 Continued.

\begin{tabular}{|c|c|c|c|c|c|c|}
\hline Sector & Location & Occ & Author & Year & Title & Journal reference \\
\hline Southern Tyrrhenian & $\begin{array}{l}\text { Stagnone } \\
\text { di Marsala }\end{array}$ & Y & Sarà et al. & 2006 & $\begin{array}{l}\text { A new Lessepsian species in } \\
\text { the western Mediterranean } \\
\text { (Brachidontes pharaonis Bivalvia: } \\
\text { Mytilidae): density, resource } \\
\text { allocation and biomass }\end{array}$ & $\begin{array}{l}\text { Marine Biodiversity } \\
\text { Records, 1, e8 }\end{array}$ \\
\hline Southern Tyrrhenian & $\begin{array}{l}\text { Termini } \\
\text { Power Plant }\end{array}$ & Y & Terranova et al. & 2006 & $\begin{array}{l}\text { Population structure of } \\
\text { Brachidontes pharaonis } \\
\text { (P. Fisher, 1870) (Bivalvia, } \\
\text { Mytilidae) in the Mediterranean } \\
\text { Sea, and evolution of a novel } \\
\text { mtDNA polymorphism }\end{array}$ & Marine Biology, 150, 89-101 \\
\hline Sicily Strait & Gabes & $?$ & No record & - & - & - \\
\hline Sicily Strait & Lampedusa & $\mathrm{N}$ & $\begin{array}{l}\text { G. Sarà, personal } \\
\text { communication }\end{array}$ & 2009 & & \\
\hline Sicily Strait & Malta & Y & Mifsud \& Cilia & 2009 & $\begin{array}{l}\text { On the presence of a colony } \\
\text { of Brachidontes pharaonis } \\
\text { (P. Fischer, 1870) (Bivalvia: } \\
\text { Mytilidae) in Maltese waters } \\
\text { (central Mediterranean) }\end{array}$ & Triton, 20, 20-22 \\
\hline Sicily Strait & Malta & $\mathrm{Y}$ & Zammit et al. & 2009 & $\begin{array}{l}\text { Occurrence of Paraleucilla } \\
\text { magna Klautau et al., } 2004 \\
\text { (Porifera: Calcarea) in Malta }\end{array}$ & $\begin{array}{c}\text { Mediterranean Marine } \\
\text { Science, 10, 135-138 }\end{array}$ \\
\hline Sicily Strait & Malta & Y & Cilia and Diedun & 2012 & $\begin{array}{l}\text { Branching out: mapping the } \\
\text { spatial expansion of the } \\
\text { Lessepsian invader mytilid } \\
\text { Brachidontes pharaonis } \\
\text { (Fischer, 1870) around } \\
\text { the Maltese Islands }\end{array}$ & $\begin{array}{l}\text { Marine Biodiversity } \\
\text { Records, 5, 1-8 }\end{array}$ \\
\hline Sicily Strait & P. Empedocle & $\mathrm{N}$ & $\begin{array}{l}\text { G. Sarà, personal } \\
\text { communication }\end{array}$ & 2009 & & \\
\hline
\end{tabular}

